\title{
New York High Line as urban catalyst: Impact to neighborhood
}

\author{
Koichiro Aitani', Vrushali Kedar Sathaye ${ }^{2}$ \\ ${ }^{1}$ Department of Architecture. Texas A\&M University, College Station, Texas, USA \\ ${ }^{2}$ Department of Urban Planning. Texas A\&M University, College Station, Texas, USA \\ E-mail:kaitani@arch.tamu.edu, sathaye.vrushali@gmail.com
}

\begin{abstract}
The High Line, an abandoned elevated railway structure on Lower Manhattan's West-side, converted into the public park is among the most innovative urban renovation projects. The meatpacking district with industrial taste, transformed to one of the most fashionable areas in New York would not be realized without the impact of this unique Urban Park, the High Line. The story of how it came to be is a remarkable one: two young citizens with no prior experience in planning and development collaborated with their neighbors, elected officials, artists, local business owners, and leaders of burgeoning movements in horticulture and landscape architecture to create a park celebrated worldwide as a model for creatively designed, socially vibrant, ecologically sound public space. More than 8 million of visitors are counted annually. The research will clarify the process of the High Line's execution, its mechanism of urban transform, and impact to the neighborhood chronologically, and will discuss and theorize this urban regeneration as an outcome of catalytic effect of Urban Green Space.
\end{abstract}

Keywords: Urban Catalyst, Urban Regeneration, Reuse, Green Network, Abandoned Elevated Railway.

\section{Introduction}

Recently, the method of urban regeneration, called "Urban Catalyst", draws more attentions in Europe and America. In this paper, "Urban Catalyst" is defined as a catalyst promoting the chained regeneration in the city, as if it acts like catalyst in the chemical reaction. Unlike the conventional development method such as "Scrap and Build" in the period of economic growth, it offers a significant character which promotes changes to the surrounding areas beyond the boundary of the development site. It would be an extremely effective method such as Japan, which is in a mature phase, not growing anymore, but, rather declining and shrinking. The point is unlike a conventional development method, urban catalyst makes changes beyond its boundary. There could be many examples observed as a result of "urban catalyst", even if they are not recognized as it is, which influenced positively around its surroundings and regenerate the areas.

This paper revolves around the interesting story of the evolution of one of the most important modes of transportation in the history of mankind. While some say its use declined over time, the stages of its metamorphosis in terms of functionality to be analyzed and confirmed its revival like a phoenix. Four important eras in the history of transportation in the United States are: The Walking-Horsecar Era, The Electric Streetcar Era, The Recreational Automobile Era and The Freeway Era. Though these eras specifically state about paradigm inventions in the field of transportation, it mainly focuses on human accessibility and mobility. No doubt that they played a key role in transforming the urban fabric, but another important invention in the history was the Railway system which was a significant step in making the world a much smaller place than it is today. 


\section{Objective}

The main objective of this paper is to study this brownfield revitalization project, and its impacts on the immediate surrounding urban fabric and its mechanism of revitalization. The meatpacking area and West Chelsea area was known for last place in Manhattan for investigation. The High Line triggered the recent development for no questions. However, in 1990's there is a movement of artists and art galleries relocating their bases from $\mathrm{SOHO}$ (South of Houston Street) to Chelsea Area. Clusters of Gallery could be observed mainly between 10th Avenue and 11th Avenue and between 20th Street to 27th Street. Also, one of the premier names in American fashion, Diane von Furstenberg was founded in 1972, and moved to the Meatpacking District in 90s. The contrast between "High-end Fashion" and Low-Key Labors of Industry, added the special attention to the district. DVF is renowned for its iconic wrap dress and signature prints, DVF has grown into the global luxury lifestyle brand it is today. The company, headquartered in New York City, has expanded to four full collections and accessories.

Those initial interventions, generated the base for regeneration and urban transformation. Further analysis will be conducted to clarify the mechanism and impact of Urban Catalyst.

\section{Literature Reviews and History of High Line}

Drawing an inspiration from the Promenade Plantée (elevated railway converted to the linear park in Paris), led to the development of this project in the West-side of Lower Manhattan. The High Line Park stretches 1.45 miles and is an elevated park on the disused New York Central Railroad also known as West Side Line. It runs from Gansevoort Street, through the Meatpacking District and Chelsea market area, and ends on the northern edge of the West Side Yard of 34th Street. The first phase of this elevated park opened in 2009 , followed by 2 nd and 3rd phases in 2011 and 2014 respectively,

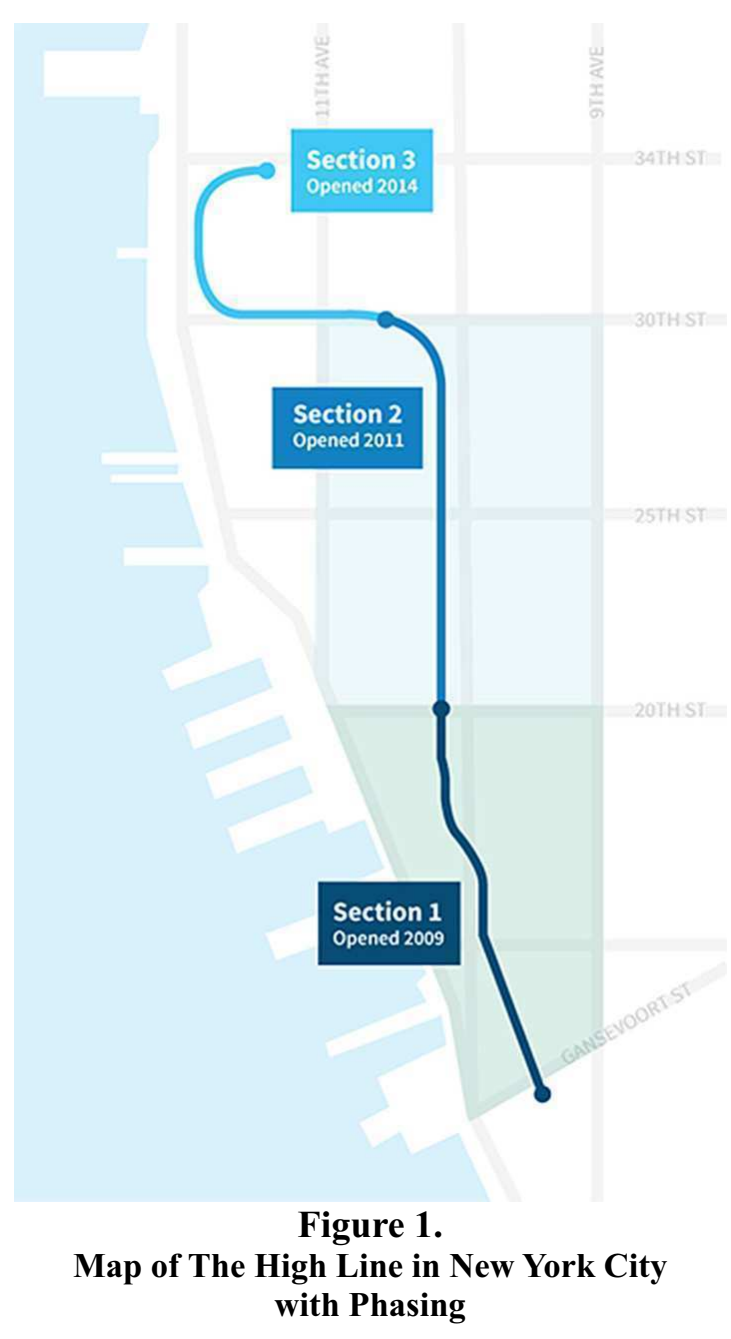

and the most recent addition to this park was the phase 4 which opened in 2015 (Lopate, 2011) (See Figure 1).

The City of New York sanctioned street level railroad tracts in downtown Manhattan's Westside to ship freight in 1847. It then hired men to wave flags in front of the trains for safety purposes. But due to high number of accidents occurring between the freight trains and other traffic it was infamously known as the "Death Avenue" (Gray, 2011). After several public debates and opposition for this hazard, finally in 1929 the city agreed to remodel the West Side Improvement Project (High Line History, 2009). The new proposal consisted of building an elevated highline that eliminated 105 street-level railroad crossings, and it was conceived by Robert Moses.

Thus, the elevated line became a transportation system which was in sync with the immediate built environment and which 


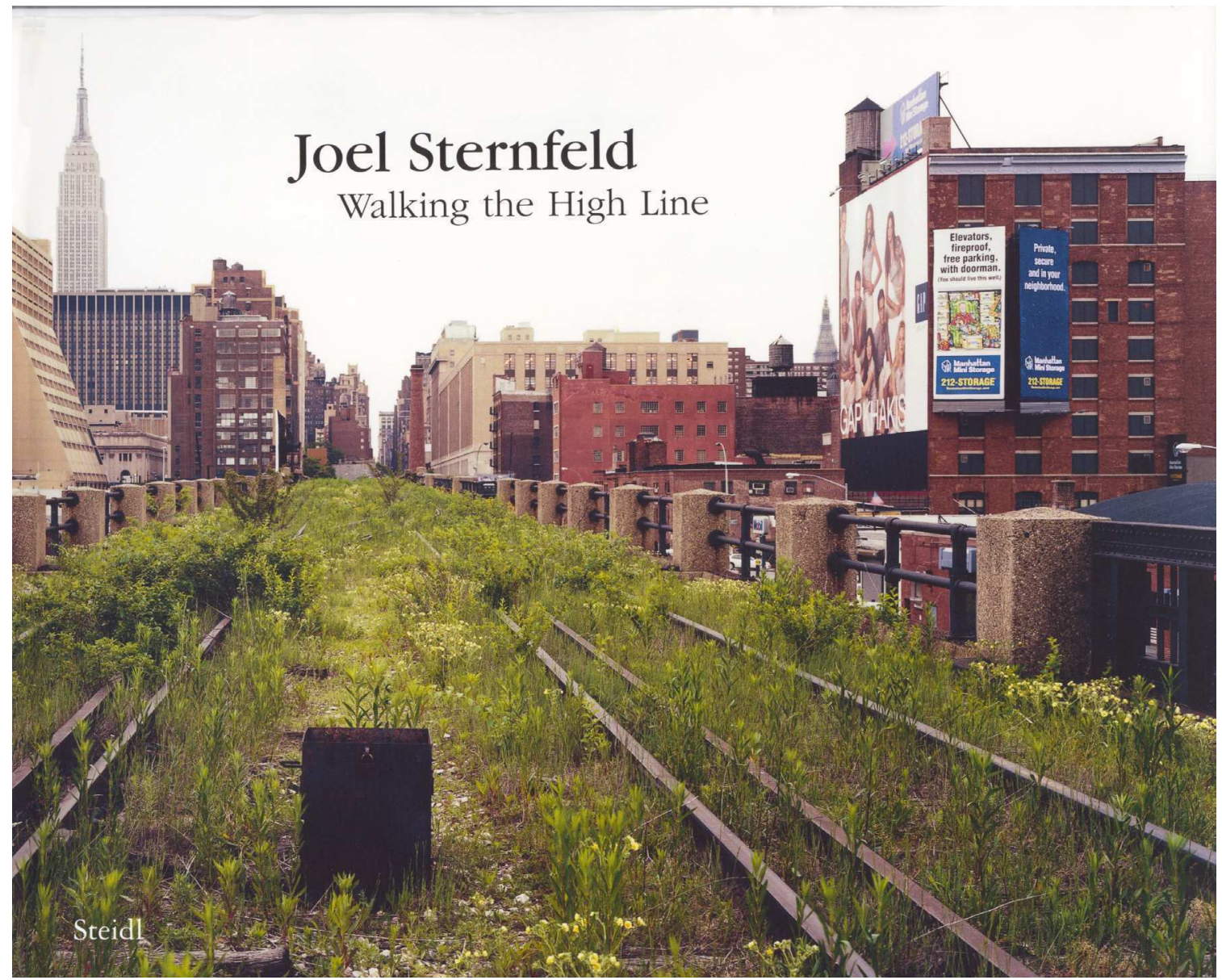

Figure 2.

Natural Vegetation on the High Line, Left Abandoned for Decades.

was able to directly connect factories and warehouses that had milk, meat packing, and manufacturing goods businesses. It helped a lot in the transportation of goods without any hindrance to the traffic on the streets. At a point in time there were hundreds of small meat packing shops operating every single day in this vicinity. Whereas today one can see a line of bars, boutiques, fashion houses, cafes and restaurants which have totally transformed this place from grit to glamour (Gregor, 2010).

The High Line is an art deco masterpiece of industrial design, massive yet elegant. It is characterized by the geometric patterns of the guard rails. It is constructed out of layers of steel and millions of rivets making it an amazing piece of engineering and construction. Due to the growth of interstate trucking in the 1950 s the rail traffic throughout the nation dropped. The last train ran on this line in the 1980s (High Line History, 2009). The High Line stayed neglected for another decade which made it a breeding ground for homeless, transsexual prostitutions, robbers and drug dealers, making it a fringe criminal pit. The residents in the neighborhood believed that it had become the main source of urban blight and so it was finally slated for demolition in the 1990s.

This is when locals Robert Hammond and Joshua David, who didn't want to see the High Line go, to save it from the wrecking ball formed the non-profit organization, "Friends of the High Line" in 1999. In the summer of 1999 when they visited the top of this elevated highline all they saw was a mile and a half of wildflowers growing up with the magnificent views of Manhattan, the Statue of Liberty, and Hudson River. This old piece of urban infrastructure had been converted into linear gardens 37 feet above ground. And then, the campaign to save the High Line gained momentum. The New Yorkers loved the idea of meadows in middle of the city (High Line History, 2009) (See Figure 2). 
This urban redesign project was addressed meticulously by the design group, associated with the Friends of Highline, New York based, Diller Scofidio + Renfro architects, and James Corner Field Operations landscape architects, up to a micro level which led to the design of elements like ramped elevated benches which stood for the elevated line, walkways and planting beds revealing exposed train tracks, seeds and grasses evoking the primal wilderness which took over after the line was abandoned. The landscaping for this place was based on the classic design principle of "scripting a path or a journey" (Trail of the Month, 2011).

The way one is brought along the High Line, the various meandering paths and turns, the varying overlooks and the dramatization of how one views the city is strongly embodied in the design. Another design idea was that of a "slow stare" i.e. when one arrives, from the busy street life, up on the High Line you get to pass from under the structure where one can almost touch the beam and the rivets, and look around at the foliage never realizing that you actually walked 3 stories up to get there. As one walks on the High Line from the southernmost terminus one can see the old, preserved landmark Chelsea market area of the city giving you an elevated view of what this industrial neighborhood looked like in the old day. Also there are dedicated places on the High Line for food vendors to sell organic and locally produced goods which bring back the essence of a food line, which brought meat and dairy into the city, synonymous to what this place was in the olden days.

Even though the vegetation looks natural, it takes a lot of efforts to maintain this artificially planted greenery (Foderaro, 2013). It is highly designed and cared for to look natural. Because the landscaping required a lot of maintenance, the city opens volunteering opportunities for the residents of the city to take part in the activities of gardening. It also opens vistas for interactions and learning. Other unique design features of this project include an urban amphitheater overlooking the busy 10th Avenue street of Manhattan, the shallow water fountains that mimic the springs and Dillervon Furstenberg sundeck plaza and which offer the wide view of the Hudson River and the western sunset (Lopate, 2011). Even though the High Line costs $\$ 100,000$ million worth of investment to build, but it generated $\$ 2$ billion worth of private investments.

Zoning Change to Prevent Gentrification

On June 23, 2005, the City Council approved the Department of City Planning's proposals for zoning text and map amendments affecting the West Chelsea area in Community District 4 Manhattan. The area is bounded generally by Tenth and Eleventh Avenues from West 30th Street south to West 16th Street. The proposal would create the Special West Chelsea District to provide opportunities for new residential and commercial development, facilitate the reuse of the High Line elevated rail line as a unique linear open space, and enhance the neighborhood's thriving art gallery district. Facilitated in large measure by the West Chelsea rezoning, the City Parks and Planning Departments, are working closely with the Friends of the High Line on the $\$ 85$ million restoration and conversion of Manhattans High Line into a lush green linear park located on the West Side (See Figure 3).

Bulk modifications were applied to 10th Avenue, 24th - 28th streets (C6-2 District): The maximum "Streetwall" height was reduced from 145 to 125 feet to ensure new development relates to the scale of existing buildings along this portion of 10th Avenue. Also, Inclusionary housing provisions were modified by the City Planning Commission and the City Council within the Special West Chelsea District to provide additional opportunities for the creation of housing for lower-, middle- and moderate-income households. Lots which have transferred floor area from the High Line Transfer Corridor would be permitted to further increase floor area through the provision of inclusionary housing in C6-3 and C6-4 districts. The preservation option of the inclusionary housing program was modified to encourage the use of this option, and the use of public subsidies was made available to encourage the use of the Inclusionary Program and ensure permanency. The use of 80/20 financing and changes to the Inclusionary Housing Bonus (IHB) described above would generate approximately 1,000 units of affordable housing as a consequence of the creation of the Special District.

The West Chelsea rezoning proposal contains 


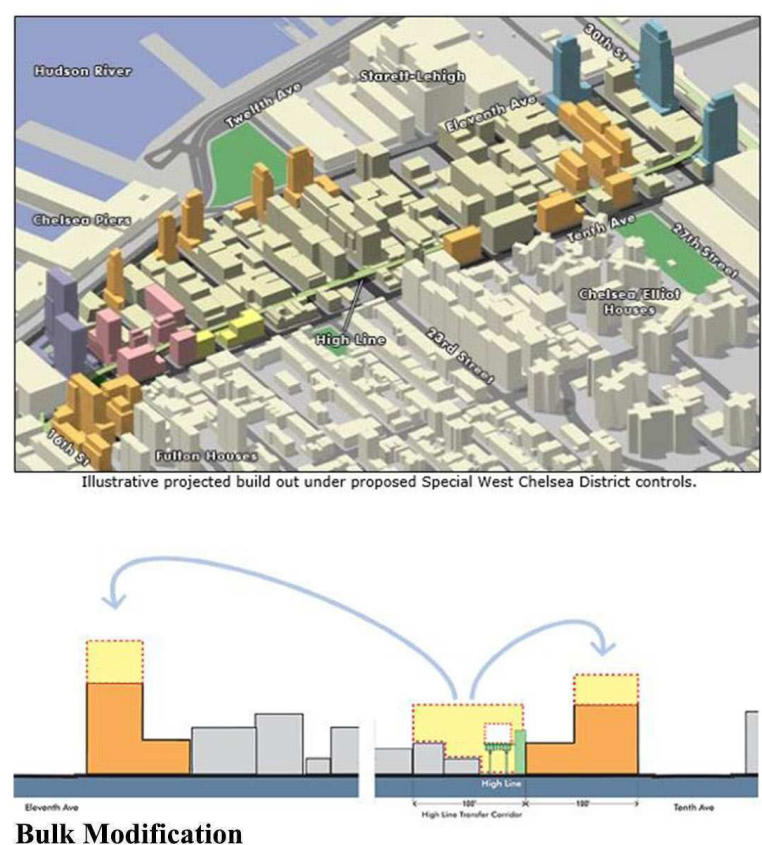

Bulk Modification

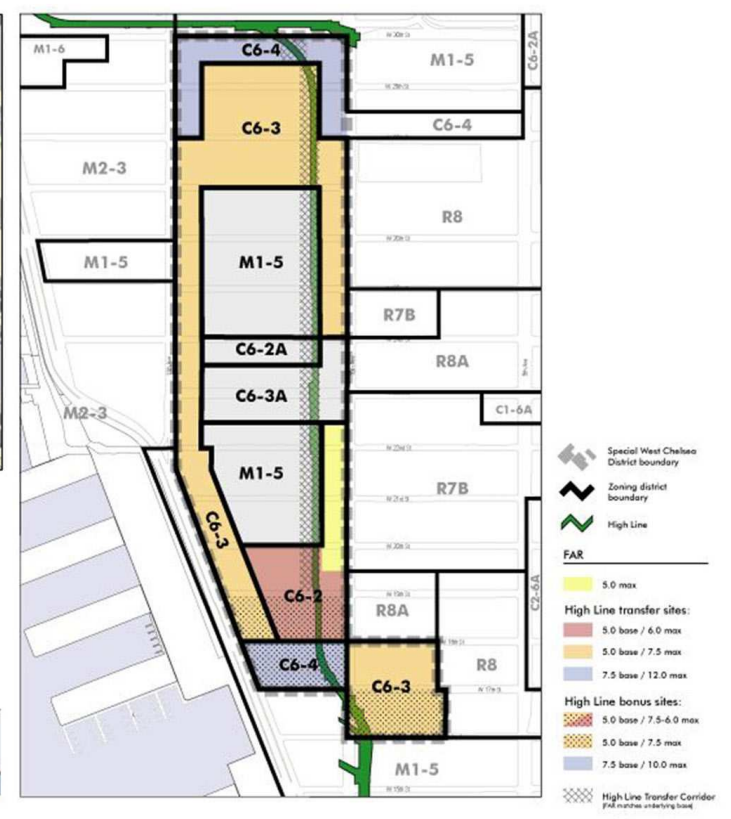

Special West Chelsea District Proposed Zoning + FAR

Figure 3.

Field work Zoning Change to West Chelsea District

provisions intended to enhance the proposed High Line open space and to ensure that adjacent developments engage with and relate to the High Line. To encourage preservation of light and air around the High Line, the proposal would allow development rights to be transferred from High Line properties to designated receiving sites within the Special West Chelsea District. New development along Tenth Avenue, adjacent to the High Line, would also be subject to a series of building bulk and use controls to encourage connections to the High Line and the preservation of light, air and views.

The rezoning proposal would create a High Line Transfer Corridor (HLTC). The HLTC would generally be 100 -feet wide and would contain the entire High Line structure and portions of adjacent lots between West 18th and West 30th Streets (indicated on the Proposed Zoning map). Owners of property within the HLTC would be permitted to transfer their development rights, equivalent to the base FAR for the property, to designated receiving sites within the Special District. The construction of stair access to the High Line would be required as a condition of the transfer on some properties. Separate site selection and acquisition actions would transfer control of the High Line to the City and would facilitate the implementation of a master plan design for the High Line open space.

The Special West Chelsea District would permit residential and commercial development along Tenth and Eleventh Avenues and on some of the midblocks, outside the core of the neighborhood's art gallery district. Regulations governing building height and setback respond to the unique features of West Chelsea, including the neighborhood's many early 20th century loft buildings, the adjacent Chelsea Historic District, and the Hudson River waterfront.

\section{Methodology}

In this research, to obtain a general and background information on the research area (Meatpacking District and West Chelsea District), GIS map of Manhattan was used as a platform of urban transformation. Series of hearing surveys were conducted, to meet with Annie White, Department of City Planning, New York City, Cub Barrett, Director of Communications, the Friends of High Line, Matthew Johnson, Associate Principal \& David Allin, Associate, Diller Scofidio + Renfro, Todd 


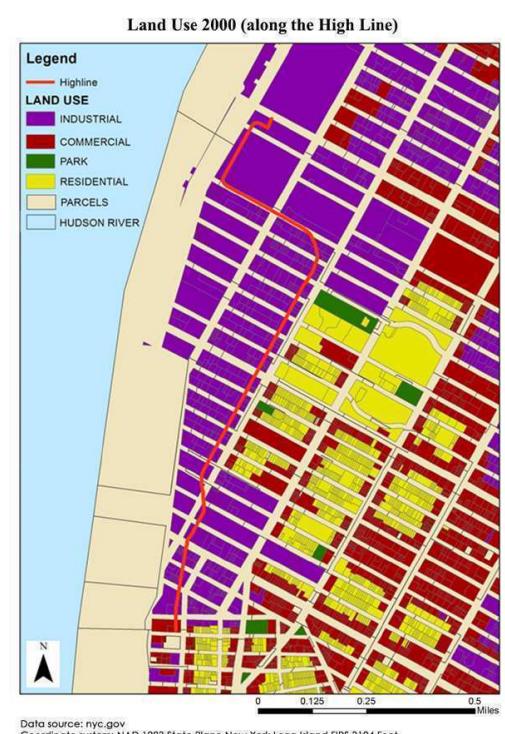

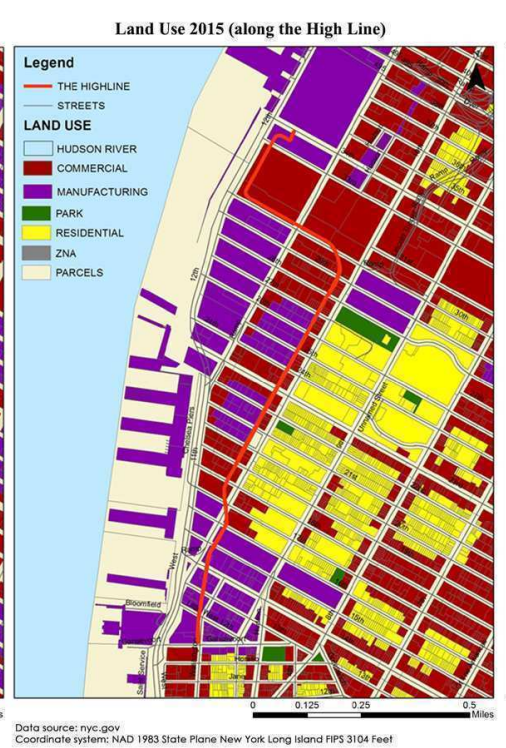

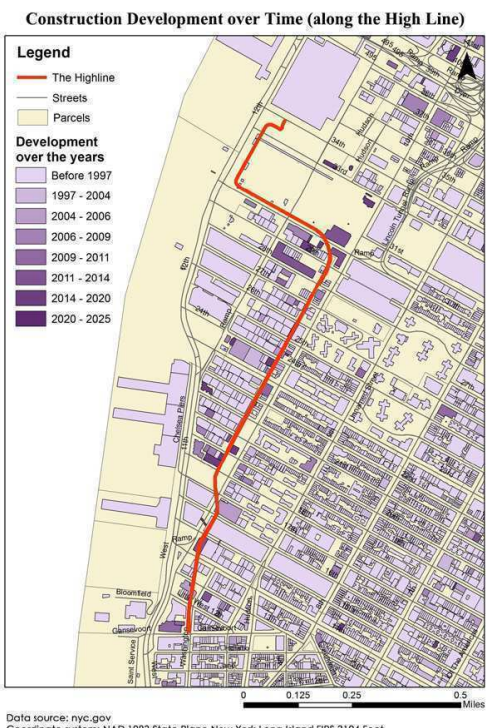

Figure 4.

Zoning (2000, 2015) and Construction Development along the High Line.

Schliemann, Partner of ENNEAD Architects LLP, etc. Also, historical maps (1891, 1920, 1930, 1950, 1970, 1990, 2010) were obtained at the New York Public Library.

West Chelsea Zoning Proposal by New York City Planning was obtained and analyzed as well as applied to the GIS map. From the Google Map, 723 businesses address and classification was obtained, and made contact to obtain the opening data of businesses.

\section{Measurement and analysis}

Figure-4 shows the change of zoning and Construction development through the year along the High Line.

723 Businesses called/researched, and information obtained based on $61.3 \%$ of 723 samples.

In summary, 91 of the surveyed businesses have been there prior to the 2000s (See Table-1).

- 2009- 1st Section of High Line Opened

- 2011-2nd Section Opened

- 2014-3rd Section Opened

Prior to initial opening: Average turnover per year: 12.3

Years following opening: Average turnover per year: 23.6

Almost a $100 \%$ increase was calculated.

\section{Property Value Changes}

The median resale price for real estate in Chelsea reached \$2,143,287 in May of 2016 . This is over 100 percent more than the real estate value in the "comparison area" just one block to the east and is over 75 percent higher than the rest of Downtown Manhattan.

Section 1 of the High Line, completed in 2009, has one of the highest resale and rental values in the area. And, Section 2 of the High Line, completed in 2011, has lower property value than section 1 , but is still $7 \%$ higher than the rest of Manhattan. Another nine buildings are under construction near the High Line, which had a median asking price of $\$ 7,122,500$ in May 2016.

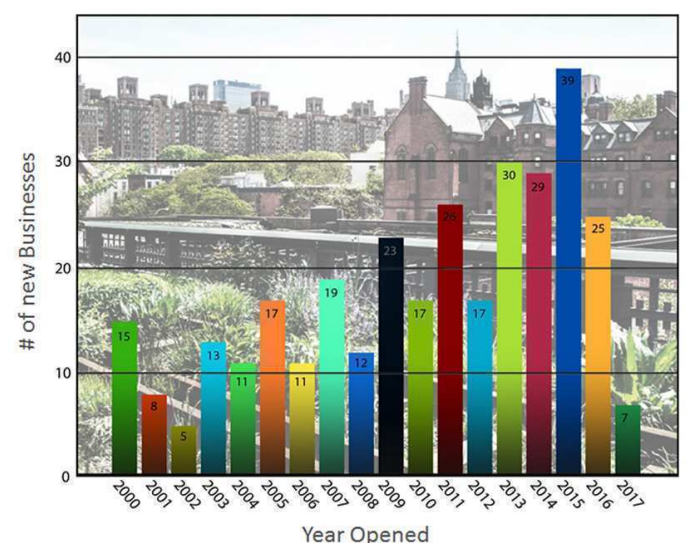

Table 1.

Year of Opening in Business around Chelsea District. 

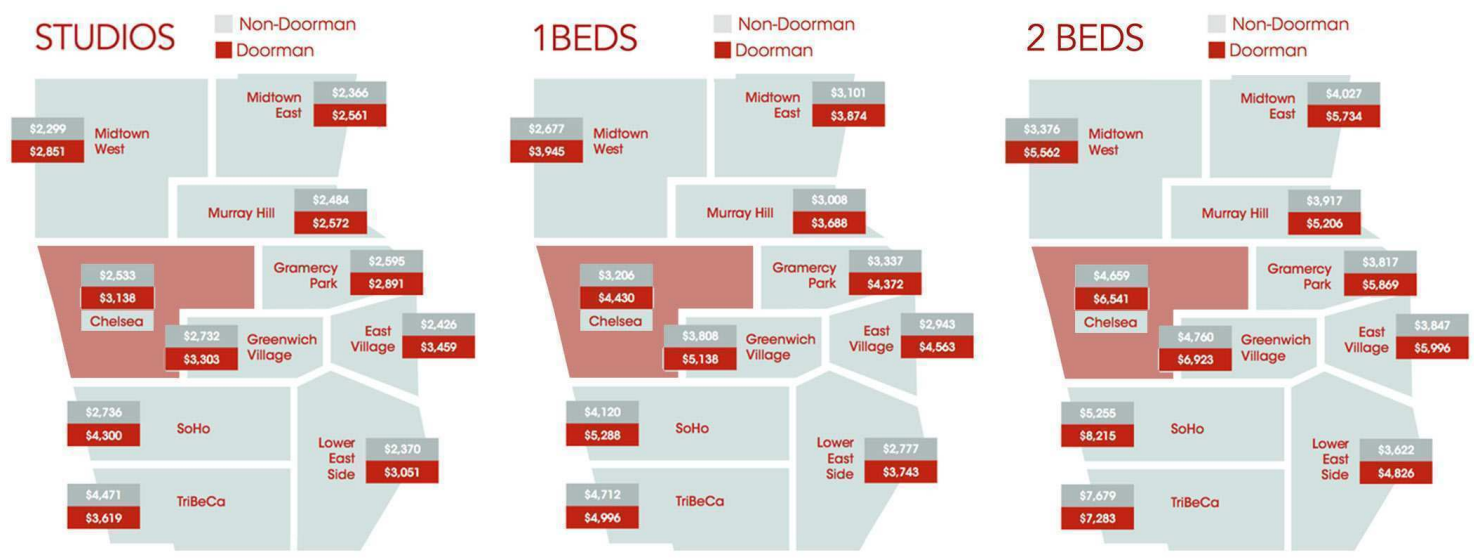

Figure 5.

Price Comparison: Chelsea District and Surrounding Districts.

In 1995, the average cost was as follows; Studio Apartment: \$1,342, One Bedroom Apartment: \$1,970, and Two Bedroom Apartment: $\$ 3,190$.

In 2009, when the Section 1 of the High Line completed, the average cost was as follows; Studio Apartment: \$2,325, One Bedroom Apartment: \$3,316, and Two Bedroom Apartment: \$5,139.

In 2011, when the Section 2 of the High Line completed, the average cost was as follows; Studio Apartment: \$2,595, One Bedroom Apartment: \$3,654, Two Bedroom Apartment: $\$ 5,646$.

In 2014, when the Section 3 of the High Line completed, the average cost was as follows; Studio Apartment: \$3,138, One Bedroom Apartment: \$4,318, and Two Bedroom Apartment: \$6,382.

Figure-5 shows the average price of apartments in category with Studios, 1 Bedroom Apartment, and 2 Bedroom Apartment (NonDoorman / Doorman).

In April of 2017 the price of rent for a studio apartment in the Chelsea district was $\$ 2,533$ without a doorman, and $\$ 3,138$ with a doorman. The district is split half and half on residences with and without doormen.

In April of 2017 the price of rent for a one bedroom apartment in the Chelsea district was $\$ 3,206$ without a doorman, and $\$ 4,430$ with a doorman. The district is split half and half on residences with and without doormen.

In April of 2017 the price of rent for a one bedroom apartment in the Chelsea district was
$\$ 4,659$ without a doorman, and $\$ 6,541$ with a doorman. The district is split half and half on residences with and without doormen.

\section{Conclusion}

Opening new businesses in both West Chelsea and Meatpacking District clarified the impact of High Line well in a higher degree. Zoning changes promoting the development along both 10th Avenue and 11th Avenue, which helps preserving the character of "Art Gallery" district, as well as preventing the gentrification. Further research is planned to investigate detailed transformation, such as street base, avenue vase, to clarify the gratitude of impact travels parallel or perpendicular to the High Line, also how those factors interact with pedestrian flows.

\section{References}

Attoe, W. and Logan, D. (1989). American Urban Architecture: Catalysts in the Design of Cities, University of California Press.

Grodacha, C. (2008). Museums as Urban Catalysts: the Role of Urban Design in Flagship Cultural Development, Journal of Urban Design, Volume 13, Issue 2, pp.195212.

James Corner Field Operations and Diller Scofidio \& Renfro (2015). The High Line (Phaidon Press).

Sternfeld, J. (2012). Joel Sternfeld: Walking 
the High Line (Steidl).

LaFarge, A. and Darke, R. (2014). On the High Line: Exploring America's Most Original Urban Park (Revised Edition).

David, J. and Hammond, R. (2011). High Line: The Inside Story of New York City's Park in the Sky (FSG Originals).

High Line History. (2009). 'Friends of the High Line', Trail of the Month. (2011).

Rails-to-Trails Conservancy. Foderaro, L. (2013). 'High Line Offers a Walk on the Wild Side', The New York Times.

Gray, C. (2011). 'When a Monster Plied the West Side', The New York Times.

Gregor, A. (2010). 'As a Park Runs Above, Deals Stir Below', The New York Times.

Lopate, P. (2011). 'Above Grade: On the High Line', Places Journal. 